\title{
Description of a new Eumenescolex species (Clitellata: Megadrili, Lumbricidae) with new data to the earthworm fauna of Corsica and Sardinia
}

\author{
T. SZEDERJESI ${ }^{1, *}$, T. PAVLÍČEK ${ }^{2} \&$ Cs. CSUZDI $^{3}$ \\ ${ }^{1}$ Tímea Szederjesi, Hungarian Natural History Museum, 1088 Budapest, Baross str. 13, Hungary \\ *E-mail: t.szederjesi@gmail.com \\ ${ }^{2}$ Tomáš Pavliček, Institute of Evolution, University of Haifa, Mount Carmel, 31905 Haifa, Israel \\ ${ }^{3}$ Csaba Csuzdi, Department of Zoology, Eszterházy Károly University, 3301 Eger, P.O. Box 43, Hungary
}

\begin{abstract}
Earthworm collectings on Corsica and Sardinia resulted in recording eight species belonging to the families Lumbricidae and Hormogastridae. Among them, Octodrilus transpadanus represents a new record for the fauna of Sardinia and Eumenescolex zoltani sp. nov. from Corsica is new to science.
\end{abstract}

Keywords. Earthworms, Lumbricidae, new species, new records, Corsica, Sardinia

\section{INTRODUCTION}

$\mathrm{S}$ ardinia is the second $\left(24,090 \mathrm{~km}^{2}\right)$ and Corsica is the fourth $\left(8,680 \mathrm{~km}^{2}\right)$ largest island of the Mediterranean Sea. Research on the earthworm fauna of these islands dates back to the beginning of the $20^{\text {th }}$ century and continued till recently. Records were published by Rosa (1893), Cognetti (1901), Chinaglia (1913), Omodeo $(1954,1984)$ and Rota (1992) on Sardinia and by Michaelsen (1926), Černosvitov (1942), Pop (1947), Bouché $(1970,1972)$ and Qiu \& Bouché (1998a, 1998b) on Corsica. There are also some data in the comprehensive works of Michaelsen (1903) and Omodeo (1961).

The distribution of autochthonous earthworm species is highly affected by paleogeographic events (Omodeo 2000, James 2004, Omodeo \& Rota 2008, Stojanović et al. 2020). The SardoCorsican system has a complex geohistory (Andeweg 2002, Meulenkamp \& Sissingh 2003, Omodeo \& Rota 2008). During the late Eocene (ca. $36 \mathrm{Mya}$ ), the Sardo-Corsican block was in connection with the Pyrenees. In the late Oligocene ( $c a .27 \mathrm{Mya}$ ), the two later islands formed an independent microplate. Sardinia was discon- nected from the Pyrenees, while Corsica was in contact with Provence and the Alpine region. At the beginning of the Miocene ( $c a$. 24 Mya), Corsica still had its land connections and Sardinia was attached to Corsica with its northeastern part, while its southwestern part was isolated. Around 20-18 Mya, this microplate collided with the Apulian microplate and remained connected till the Tortonian (ca. 9 Mya) (Salvo et al. 2010). The Messinian salinity crisis (5.9-5.3 Mya) was the next period that gave the opportunity for fauna exchanges through establishing new land connections. During the Pleistocene Ice Age, due to the repeating decrease of the sea level, Corsica and Sardinia were again connected to the Italian peninsula and probably also to Provence, which could have opened migration corridors as well.

This geotectonic complexity is well-reflected by the distribution of the different earthworm taxa inhabiting the islands (Bouché 1983, Omodeo \& Rota 1987, 2008). According to Omodeo \& Rota (2008), the autochthonous fauna is originated mostly from Catalonia, and in a smaller part from Provence. The islands' most characteristic earthworm genera from the family Lumbricidae are Eumenescolex, Diporodrilus, Prosellodrilus and 
Scherotheca. The genus Eumenescolex has seven species and subspecies, of which two (Eum. heideti Qiu \& Bouché, 1998 and Eum. emiliae Qiu \& Bouché, 1998) live in Corsica, while Eum. gabriellae gabriellae (Omodeo, 1984) and Eum. g. gallurae (Omodeo, 1984) are distributed in Sardinia. The six species and subspecies of $D i-$ porodrilus are restricted to Corsica (Di. pilosus pilosus Bouché, 1970, Di. p. minimus Bouché, 1970, Di. omodeoi omodeoi Bouché, 1970, Di. o. postheca Bouché, 1970) and Sardinia (Di. bouchei Omodeo, 1984, Di. sp. and Di. pilosus). Most species of Prosellodrilus are found in Catalonia and the Pyrenees. Pr. festae (Rosa, 1892) was originally described from the surroundings of Tunis and was later recorded from Sardinia (Omodeo 1954). Omodeo \& Rota (2008) also reported the presence of a still undescribed Prosellodrilus species from the island. The genus Scherotheca has several species distributed from the Pyrenees to the Western Alps. The subgenus Sche. (Corsicadrilus) and subspecies Sche. (Rosanus) dugesi brevisella Bouché, 1972 are endemic to Corsica.

The Western Mediterranean family Hormogastridae is represented with three species belonging to two genera (Omodeo \& Rota 2008, Marchán et al. 2018). Hormogaster redii Rosa, 1887 is the most widespread species found on both islands and also on the continent from Tuscany to the island of Sicily. H. samnitica Cognetti, 1914 is distributed on Corsica, Northern Sardinia and in the northern part of the Italian peninsula. Norana pretiosa (Michaelsen, 1899) is endemic to Sardinia.

A recently elaborated earthworm material collected on Corsica and Sardinia in 1974 and 2006 resulted in recording eight species from the family Lumbricidae and Hormogastridae, including a new fauna record for Sardinia and an Eumenescolex species new to science from Corsica.

\section{MATERIAL AND METHODS}

Earthworms were collected by digging and hand-sampling. The specimens were killed in $75 \%$ ethanol and preserved in $75 \%$ ethanol or $4 \%$ formaldehyde solution, and deposited in the earthworm collection of the Hungarian Natural History Museum (HNHM).

The collecting localities are shown on Figure 1 , the locality numbers are indicated with italics in the text. We don't have exact locality data for Norana pretiosa (Michaelsen, 1899) therefore it is not indicated on the map.
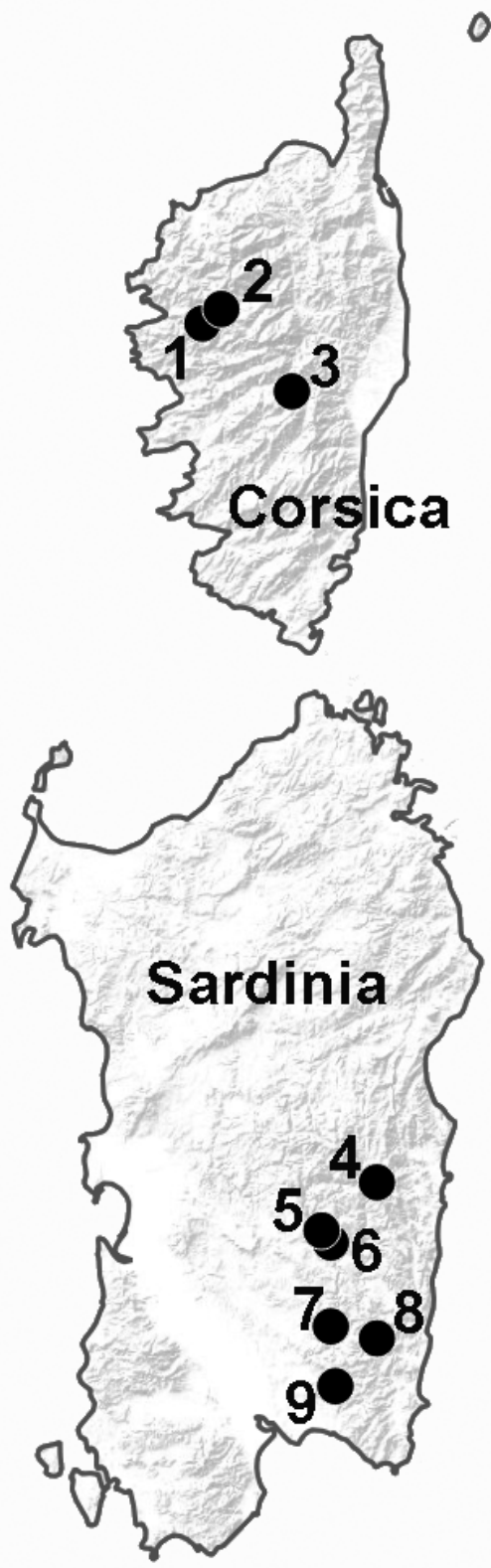

Figure 1. Collection sites in Corsica and Sardinia. Numbers refer to the locality numbers in the text. 


\section{RESULTS}

\section{Family Lumbricidae Rafinesque-Schmaltz, 1815}

\section{Aporrectodea caliginosa (Savigny, 1826)}

Enterion caliginosum Savigny, 1826: 180.

Allolobophora caliginosa: Omodeo 1984: 116. Omodeo \& Rota 1987: 202.

Nicodrilus caliginosus: Rota 1992: 1385.

Aporrectodea caliginosa caliginosa: Csuzdi 2012.

Material examined. HNHM/17630 2 ex., No. 8. Italy, Sardinia, along Flumendosa river after San Vito in direction to mountains, N39 $9^{\circ} 9^{\prime}$, E09 $9^{\circ} 27^{\prime}$, 08.10.2006, leg. T. Pavlíček. HNHM/17632 2 ex., No. 4. Italy, Sardinia, near a small river from Lago Alto del Flumendosa, N39 55', E09 27', 08.10.2006, leg. T. Pavlíček.

\section{Aporrectodea rosea (Savigny, 1826)}

Enterion roseum Savigny, 1826: 182.

Eisenia rosea f. bimastoides: Cognetti, 1901: 17.

Helodrilus (Eisenia) roseus f. typicus: Chinaglia 1913: 2.

Helodrilus (Eisenia) roseus f. bimastoides: Chinaglia 1913: 2.

Allolobophora rosea f. bimastoides: Omodeo 1954: 6.

Allolobophora rosea: Omodeo 1984: 116. Omodeo \& Rota 1987: 202. Rota 1992: 1385.

Aporrectodea rosea: Csuzdi 2012.

Material examined. HNHM/17629 1 ex., No. 7. Italy, Sardinia, near a small river between S. Basilio and Silius, N39 $31^{\prime}$ E09 ${ }^{\circ} 17^{\prime}$, 08.10.2006, leg. T. Pavlíček.

\section{Dendrobaena pantaleonis (Chinaglia, 1913)}

Helodrilus (Bimastus) pantaleonis Chinaglia, 1913: 5. Bimastus (?) pantaleonis: Omodeo 1954: 4.

Dendrobaena pantaleonis: Omodeo 1984: 116. Omodeo \& Rota 1987: 202.

Material examined. HNHM/17633 1 ex., No. 4. Italy, Sardinia, near a small river from Lago Alto del Flumendosa, N39 $55^{\prime}$ E09 ${ }^{\circ} 27^{\prime}$, 08.10. 2006, leg. T. Pavlíček.

\section{Eiseniella tetraedra (Savigny, 1826)}

Enterion tetraedrum Savigny, 1826: 184.

Eiseniella tetraedra subsp. typica: Cognetti 1901: 17.

Helodrilus (Eiseniella) tetraedrus typicus: Chinaglia 1913: 2.

Allolobophora (Eiseniella) tetraedra f. typica: Michaelsen 1926: 1.

Eiseniella tetraedra f. typica: Černosvitov 1942: 219. Pop 1947: 11.

Eiseniella tetraedra: Omodeo 1954: 6; 1984: 116. Omodeo \& Rota 1987: 203. Rota 1992: 1385.

Material examined. HNHM/17628 1 ex., No. 6. Italy, Sardinia, $3 \mathrm{~km}$ from Esterzili, N39 $45^{\prime}$ E09 ${ }^{\circ} 7^{\prime}, 09.10 .2006$, leg. T. Pavlíček. HNHM/ 176421 ex., No. 1. France, Corsica, E of Evisa, spring outlet at the Corte-Ajaccio crossroad (roads D84-D70), N42.253370 , E8.820180, $938 \mathrm{~m}$, 04.05.2006, leg. Z. Barina.

\section{Eumenescolex zoltani sp. nov.}

(Figure 2)

urn: 1sid:zoobank.org:act:35D1868F-E992-4E07-B1F4E3DB009BEF30

Holotype. HNHM/17639 No. 3. France, Corsica, NE slope of Mt. Punta Bacinello, stream Sce de Pizzolo, N42.071740 ${ }^{\circ}$ E9.143020, $1882 \mathrm{~m}$, 05.05.2006, leg. Z. Barina. Paratypes. HNHM/ 176401 ex., locality and date same as that of the Holotype. HNHM/17641 1 ex., No. 2. France, Corsica, Domaniale de Valdu Niellu, tributary of the Golo River along the road D84, N42.292080 ${ }^{\circ}$ E8.888240 ${ }^{\circ}, 1330 \mathrm{~m}, 05.04 .2006$, leg. Z. Barina.

Diagnosis. Length 65-110 mm, diameter 5-6 $\mathrm{mm}$, setae closely paired. Colour pale. First dorsal pore in 10/11. Clitellum on (23) $24-35$, tubercles on $1 / 227-1 / 233$. Male pores on 15 , surrounded by glandular crescents. Nephridial pores irregularly alternate between $b$ and above $d$. Two pairs of vesicles in 11,12 . Spermathecae two pairs in $12 / 13,13 / 14$, open in $c d$. Calciferous diverticula in 10. Nephridial bladders J-shaped, reclinate.

External characters. Holotype $65 \mathrm{~mm}$ long and $5 \mathrm{~mm}$ wide, tail truncated. Number of segments 129. Paratypes $80-110 \mathrm{~mm}$ long and 5-6 
mm wide. Number of segments 189-205. Secondary annulations between segments 10-24. Colour pale, pigmentation lacking. Prostomium epilobous, 1/3 closed. First dorsal pore at intersegmental furrow 10/11. Setae closely paired, setal arrangement behind clitellum: $a a: a b: b c: c d: d d=$ 10:1.5:7:1:30. Male pores on segment 15, surrounded by glandular crescents, protruding into the neighbouring segments. Nephridial pores irregularly alternate between setal line $b$ and above $d$. Clitellum on (23) 24-35. Tubercula pubertatis on $1 / 227-1 / 233$. Glandular tumescences on $14,15,16,27,34,35 a b$.

Internal characters. Septa 5/6-6/7 thickened, 7/8-9/10 strongly strengthened. Testes and funnels paired in 10-11. Two pairs of seminal vesicles in 11 and 12. Spermathecae two pairs in $12 / 13,13 / 14$ with external openings near setal line $c d$. The left spermatheca in 13/14 of the Holotype doubled, the others single. Calciferous glands in 10-14, with lateral diverticula in 10. Last pair of hearts in 11, with a pair of extraoesophageal vessel in 12. Nephridial bladders J-shaped, reclinate. Crop in 15-16, gizzard in 17-18. Typhlosolis large, simple, lamelliform. Longitudinal musculature of intermediate type.

Etymology. The new species is dedicated to the collector and our colleague, Dr. Zoltán Barina.

Remarks. Eum. zoltani sp. nov. differs well from the other Eumenescolex species in the position of the clitellum and especially in its long tubercles. Their main characters are summarized in Table 1.
Qiu \& Bouché (1998a) listed all Eumenescolex species as having nephridial pores aligned near setal line $b$ except Eum. simplex (Zicsi, 1981), from which they didn't have exact data. Investigation of the type specimens of Eum. simplex revealed that this species has irregularly alternating nephridial pores, just like Eum. zoltani sp. nov. Therefore, it would be worthwhile to reinvestigate all the other Eumenescolex species from this point of view.

\section{Octodrilus transpadanus (Rosa, 1884)}

Allolobophora transpadana Rosa, 1884: 45. Octodrilus transpadanus: Csuzdi 2012.

Material examined. HNHM/17631 1 ex., No. 8. Italy, Sardinia, along Flumendosa river after San Vito in direction to mountains, N39 $29^{\prime}$ E09²7’, 08.10.2006, leg. T. Pavlíček.

Remark. This is the first data of the TransAegean Oc. transpadanus from Sardinia.

\section{Family Hormogastridae Michaelsen, 1900}

\section{Hormogaster redii Rosa, 1887}

Hormogaster redii Rosa, 1887: 1. Cognetti 1901: 16. Michaelsen 1903: 134. Chinaglia 1913: 2. Omodeo 1954: 6; 1984: 116. Omodeo \& Rota 1987: 202. Rota 1992: 1385.

Material examined. HNHM/AF5756 1 ex., No. 4. Italy, Sardinia, mountains near Lago Alto del Flumendosa, N39 ${ }^{\circ} 55^{\prime}$ E09 ${ }^{\circ} 27^{\prime}, 08.10 .2006$, leg. T. Pavlíček. HNHM/AF5757 1 ex., No. 5. Italy,

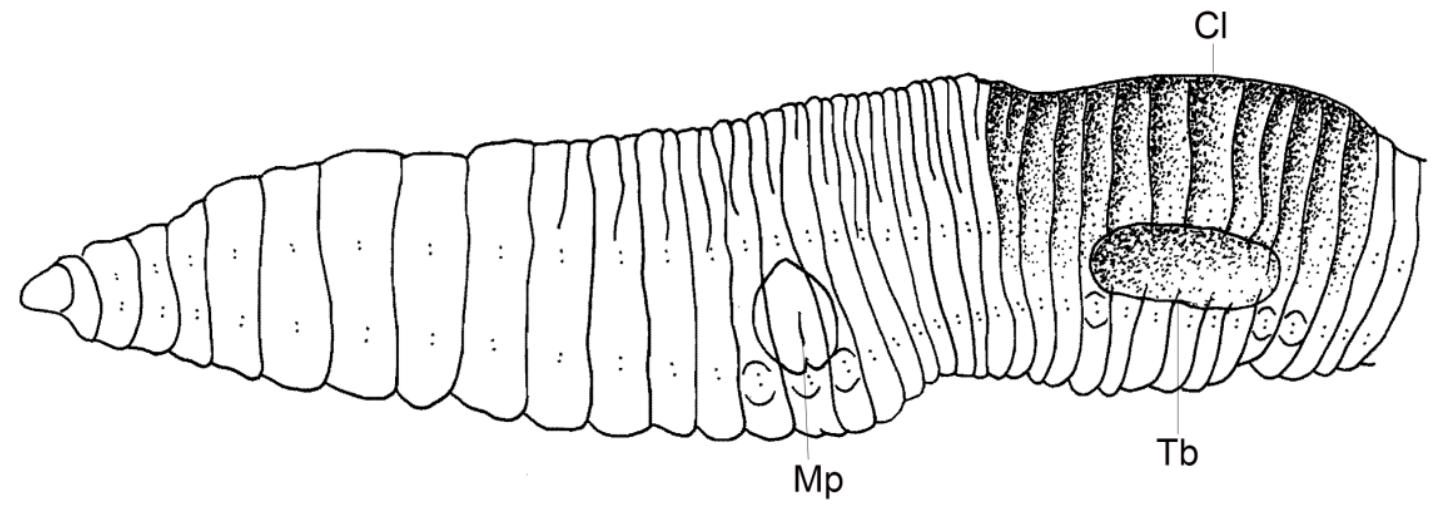

Figure 2. Eumenescolex zoltani sp. nov. Lateral view of the fore body. $\mathrm{Cl}=$ Clitellum, $\mathrm{Mp}=$ Male pore, $\mathrm{Tb}=$ Tubercles. 
Table 1. Main distinguishing characters of the Eumenescolex species.

\begin{tabular}{|c|c|c|c|c|c|c|}
\hline Taxon & $\begin{array}{l}\text { Length } x \text { width } \\
(\mathrm{mm})\end{array}$ & $\begin{array}{l}\text { Segment } \\
\text { No. }\end{array}$ & Clitellum & Tubercles & Vesicles & Spermathecae \\
\hline Eum. zoltani sp. nov. & $65-110 \times 5-6$ & 129-205 & (23) $24-35$ & $1 / 227-1 / 233$ & 11,12 & $\begin{array}{l}12 / 13,13 / 14 \\
c d\end{array}$ \\
\hline $\begin{array}{l}\text { Eum. heideti Qiu \& Bouché, } \\
1998\end{array}$ & $37-40 \times 1.5-2.5$ & $130-131$ & (25) 26-33 & $29-30(1 / 331)$ & $9-12$ & $13 / 14 c$ \\
\hline $\begin{array}{l}\text { Eum. gabriellae gabriellae } \\
\text { (Omodeo, 1984) }\end{array}$ & $40-70 \times 2.1-3.5$ & $99-159$ & $\begin{array}{l}\text { (21) } 22-30 \\
31(1 / \mathrm{n} 32)\end{array}$ & (23) 25-27 (28) & $\begin{array}{l}9,11 \\
12\end{array}$ & $13 / 14 c$ \\
\hline $\begin{array}{l}\text { Eum. gabriellae gallurae } \\
\text { (Omodeo, 1984) }\end{array}$ & - & - & $24-34$ & $27-30(31)$ & $\begin{array}{l}9,11 \\
12\end{array}$ & $13 / 14 c$ \\
\hline Eum. pereli (Bouché, 1972) & $40-80 \times 2.5-5$ & $105-206$ & $23-30$ & $\begin{array}{l}(3 / 425) 26-28 \\
(1 / 429)\end{array}$ & 11,12 & $12 / 13,13 / 14 c$ \\
\hline $\begin{array}{l}\text { Eum. emiliae Qiu \& Bou- } \\
\text { ché, } 1998\end{array}$ & $93-105 \times 2-3$ & $156-161$ & $26-33$ & $\begin{array}{l}(1 / \mathrm{n} 28) 29-32 \\
(33)\end{array}$ & 11,12 & $12 / 13,13 / 14 c$ \\
\hline Eum. simplex (Zicsi, 1981) & $105-112 \times 5-7$ & $99-154$ & $26-1 / 236$ & $29-1 / 233$ & $9-12$ & $13 / 14 c$ \\
\hline $\begin{array}{l}\text { Eum. proclitellatus Perez- } \\
\text { Onteniente \& Rodri- } \\
\text { guez-Babio, } 2004\end{array}$ & $31-46 \times 2.1-2.8$ & $119-137$ & $23-34$ & $1 / 228,29-32$ & $?$ & $11 / 12-13 / 14 c$ \\
\hline
\end{tabular}

Sardinia, $2 \mathrm{~km}$ to Sadali near the road from Esterzili, N39 $47^{\prime}$ E09 ${ }^{\circ} 5^{\prime}, 09.10 .2006$, leg. T. Pavlíček. HNHM/AF5758 1 ex., No. 9. Italy, Sardinia, oak forest near Burcei, N39 $21^{\prime}$ E09¹8', 08.10.2006, leg. T. Pavlíček.

\section{Norana pretiosa (Michaelsen, 1899)}

Hormogaster praetiosa Michaelsen, 1899: 445. Hormogaster pretiosa: Cognetti 1901: 17. Omodeo 1954: 6; 1984: 116. Omodeo \& Rota 1987: 202.

Nora pretiosa: Marchán et al. 2018a: 667.

Norana pretiosa: Marchán et al. 2018b: 89.

Material examined. HNHM/AF3376 4 ex., Italy, Sardinia, 24.10.1974, leg. L. Gozmány.

\section{DISCUSSION}

The newly elaborated earthworm material from Corsica and Sardinia resulted in recording six species from the family Lumbricidae and two from Hormogastridae. Among them, Ap. caliginosa, Ap. rosea and Eis. tetraedra are introduced peregrine species. D. pantaleonis was originally described from Sardinia but was later recorded from Albania, Greece, Turkey (Sze- derjesi 2018) and Cyprus (Pavlíček \& Csuzdi 2016).

Omodeo \& Rota (2008) stated that the genus Octodrilus is missing from Sardinia however, Michaelsen (1903) reported the presence of the Circum-Mediterranean Oc. complanatus (Dugès, 1828) from the island. Omodeo (1954) mentioned this literature record; however during his many sampling campaigns in Sardinia he never recovered this well-known species, which led him to the conclusion that Michaelsen's record was a misprint or a misidentification. Now the recent collectings showed that the widely distributed Trans-Aegean Oc. transpadanus is present on Sardinia, as well.

The new species Eum. zoltani sp. nov. differs well morphologically from the other Eumenescolex species. The specimens were found on two localities in the central part of Corsica, while the other two Corsican Eumenescolex species (Eum. heideti and Eum. emiliae) occur in the southern part of the island.

According to Qiu \& Bouché (1998c), the genus Eumenescolex is morphologically relatively 
diverse. The species' common characteristics are the absence of pigmentation, the similarity in the position of their clitellar organs and their small or middle sized body dimensions. However, there are differences in the number and position of the spermathecae, the number of vesicles and in the position of the nephridial pores.

The Corsican endemic subgenus Scherotheca (Corsicadrilus) shares some similarity with Eumenescolex, but their brownish or greyish pigmentation, the position of their clitellar organs, their commonality in the number of vesicles (four pairs in each species) and the number, position and the possible duplication of their spermathecae prove that they stand close to the other Scherotheca species.

Acknowledgement - We are grateful to all collectors of the material.

\section{REFERENCES}

ANDEWEG, B. (2002): Cenozoic Tectonic Evolution of the Iberian Peninsula, Causes and Effects of Changing Stress Fields. Ph.D. thesis. Vrije Universiteit Amsterdam, Amsterdam, 178 pp.

BouCHÉ, M.B. (1970): Remarques sur quelques Lumbricina de France et consequences de la découverte des nouveaux taxons Vignysinae (Subfam. nov.) et Diporodrilidae (Fam. nov.). Pedobiologia, 10: 246256.

BouchÉ, M.B. (1972): Lombriciens de France: Écologie et systematique. Annales de Zoologie-Écologie Animale, numero hors-série, INRA, Paris, pp. 671.

BouCHÉ, M.B. (1983): The establishment of earthworm communities. In: SATCHELL, J.E. (Ed.): Earthworm Ecology. From Darwin to vermiculture. Chapman and Hall, London, New York, p. 431448. doi: 10.1007/978-94-009-5965-1_38

Chinaglia, L. (1913): Escursioni Zoologiche in Sardegna del dr. Enrico Festa. III. Lombrichi. Bollettino Musei di Zoologia ed Anatomia comparata della R. Università di Torino, 28(667): 1-6.

Cognetti, L. (1901): Gli Oligocheti della Sardegna. Bollettino Musei di Zoologia ed Anatomia com- parata della $R$. Università di Torino, 16(404): 126.

ČERNOSVITOV, L. (1942): Oligochaeta from various parts of the world. Proceedings of the Zoological Society of London, 111: 197-236.

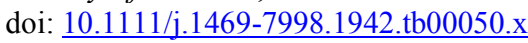

CsuZDI, Cs. (2012): Earthworm species, a searchable database. Opuscula Zoologica Budapest, 43(1): 9799. doi: $\underline{10.5281 / \text { zenodo. } 1045525}$

JAMES, S.W. (2004): Planetary processes and their interactions with earthworm distributions and ecology. In: EDWARDS, C.E. (Ed.): Earthworm Ecology. CRC Press, Boca Raton, pp. 53-62. doi: $\underline{10.1201 / 9781420039719 . p t 2}$

Marchán, D.F., Fernández, R., De Sosa, I., SÁNCHEz, N., DÍAz Cosín, D.J. \& Novo, M. (2018a): Integrative systematic revision of a Mediterranean earthworm family: Hormogastridae (Annelida, Oligochaeta). Invertebrate Systematics, 32: 652671. doi: $10.1071 / \mathrm{IS} 17048$

MARchÁN, D.F., FERnÁNDEZ, R., SÁNCHEZ, N., DE SosA, I., DíAz Cosín, D.J. \& Novo, M. (2018b): Insights into the diversity of Hormogastridae (Annelida, Oligochaeta) with descriptions of six new species. Zootaxa, 4496(1): 065-095. doi: 10.11646/zootaxa.4496.1.6

MeulenKamP, J.E. \& Sissingh, W. (2003): Tertiary palaeogeography and tectonostratigraphic evolution of the Northern and Southern Peri-Tethys platforms and the intermediate domains of the African-Eurasian convergent plate boundary zone. Palaegeography, Palaeoclimatology and Palaeoecology, 196: 209-228. doi: 10.1016/S0031-0182(03)00319-5

MICHAELSEN, W. (1903): Die geographische Verbreitung der Oligochaeten. Friedlander \& Sohn, Berlin. doi: $\underline{10.5962 / \text { bhl.title.11667 }}$

MichaElSEN, W. (1926): Beiträge zur Kenntnis der Land-und Süsswasserfauna Korsikas. 3. Lumbriciden. Mitteilungen aus dem Museum für Naturkunde in Berlin, 12: 223-227.

OMODEO, P. (1954): Problemi faunistici riguardanti gli Oligocheti terricoli della Sardegna. Atti della Società Toscana di Scienze Naturali, 61: 3-15.

OMODEO, P. (1961): Le peuplement des grandes iles de la Méditerranée par les Oligochètes terricoles. Colloques Internationaux $d u$ Centre National de la Recherche Scientifique, 94: 128-133. 
OMODEO, P. (1984): The earthworm fauna of Sardinia. Revue d'Écologie et Biologie du Sol, 21: 115-126.

OMODEO, P. (2000): Evolution and biogeography of megadriles (Annelida, Clitellata). Italian Journal of Zoology, 67: 179-201. doi: $10.1080 / 11250000009356313$

OMODEO, P. \& Rota, E. (1987): Caractères originaux des peuplements des îles tyrrhéniennes en Oligochètes terricoles. Bulletin de la Société Zoologique de France, 112(1-2): 197-214.

OMODEO, P. \& ROTA, E. (2008): Earthworm Diversity and Land Evolution in Three Mediterranean Districts. Proceedings of the California Academy of Sciences, Fourth Series, 59(suppl. 1): 65-83.

PAVlíČEK, T. \& CsuzDI, Cs. (2016): Clitellata: Oligochaeta. In: Sparrow, D.J. \& JOHN, E. (Eds.) An introduction to the wildlife of Cyprus. Terra Cypria, Lefkosia, Cyprus, pp. 587-599.

PoP, V. (1947): Lombriciens de la Corse. Archives de Zoologie Expérimentale et Générale, 85(1): 1-18.

QIU, J-P. \& BOUCHÉ, M. (1998a): Eumenescolex, nouveau genre de Lumbricidae (Annelida: Oligochaeta). Documents pédozoologiques et intégrologiques, 4: 3-7.

QIU, J-P. \& BOUCHÉ, M. (1998b): Révision morphologique, chorologique et taxonomique du genre Scherotheca Bouché, 1972 (Oligochaeta: Lumbricidae). Documents pédozoologiques et intégrologiques, 4: 117-139.

QIU, J-P. \& BouchÉ, M. (1998c): Révision des taxons supraspécifiques de Lumbricoidea. Documents pédozoologiques et intégrologiques, 3: 179-224.

RosA, D. (1884): Lumbricidi del Piemonte. Stamperia dell'Unione Tipografico-Editrice, Torino, pp. 54.
RosA, D. (1887): Hormogaster redii n. g., n. sp. Bollettino dei Musei di Zoologia ed Anatomia comparata della $R$. Universitá di Torino, 32(2): 12 .

RosA, D. (1893): Revisione dei Lumbricidi. Memorie dell'Accademia delle Scienze di Torino, 43: 339476.

RotA, E. (1992): New data on the earthworm fauna of Gallura (Northeast Sardinia). Soil Biology and Biochemistry, 24(12): 1383-1388. doi: 10.1016/0038-0717(92)90122-E

Salvo, G., Ho, S.Y.W., Rosenbaum, G., ReE, R. \& CONTI, E. (2010): Tracing the Temporal and Spatial Origins of Island Endemics in the Mediterranean Region: A Case Study from the Citrus Family (Ruta L., Rutaceae). Systematic Biology, 59(6): 705-722. doi: $\underline{10.1093 / \text { sysbio/syq046 }}$

SAVIGNY, J.C. (1826): In: G. Cuvier: Analyse des Travaux de l'Academie royale des Sciences, pendant l'année 1821, partie physique. Mémoires de l'Académie des Sciences de l'Institut de France Paris, 5: 176-184.

Stojanović, M., Tsekova, R., Trakić, T. \& SEKULIĆ, J. (2020): On the presence of the endemic earthworm Dendrobaena rhodopensis (Černosvitov, 1937) in the Balkan Peninsula: biogeographical consideration and conservation status. North-Western Journal of Zoology, 16(1): 59-63.

SZEDERJESI, T. (2018): The first combined checklist of earthworms of the Northeastern Mediterranean region (Clitellata: Megadrili). Opuscula Zoologica Budapest, 48(2): 77-116. doi: $10.18348 /$ opzool.2017.2.77 